Trauma Surgery \& Acute Care Open

\title{
Challenge of uncontrolled enteroatmospheric fistulas
}

\author{
Daniel Jonathan Gross (10, ${ }^{1}$ Michael C Smith, ${ }^{2}$ Bardiya Zangbar-Sabegh, ${ }^{3}$ \\ Kenneth Chao, ${ }^{4}$ Erin Chang, ${ }^{1}$ Leon Boudourakis, ${ }^{3}$ Muthukumar Muthusamy, ${ }^{3}$ \\ Valery Roudnitsky, ${ }^{3}$ Tim Schwartz ${ }^{3}$
}

\begin{abstract}
'Surgery, State University of New York Downstate Medical Center, Brooklyn, New York, USA ${ }^{2}$ Surgery, Vanderbilt University Medical Center, Nashville, Tennessee, USA

${ }^{3}$ Surgery, Kings County Hospital Center, Brooklyn, New York, USA ${ }^{4}$ Emergency Medicine, State University of New York Downstate Medical Center, Brooklyn, New York, USA
\end{abstract}

\section{Correspondence to}

Dr Daniel Jonathan Gross, Surgery, State University of New York Downstate Medical Center, Brooklyn, NY 11203, USA; daniel.gross@downstate.edu

14th Academic Surgical Congress. Houston, Texas 2019

Received 12 September 2019 Revised 18 November 2019 Accepted 8 December 2019
(C) Author(s) (or their employer(s)) 2019. Re-use permitted under CC BY-NC. No commercial re-use. See rights and permissions. Published by BMJ.

To cite: Gross DJ, Smith MC, Zangbar-Sabegh B, et al. Trauma Surg Acute Care Open 2019:4:e000381.

\section{ABSTRACT}

Introduction With the popularization of damage control surgery and the use of the open abdomen, a new permutation of fistula arose; the enteroatmospheric fistula (EAF), an opening of exposed intestine spilling uncontrollably into the peritoneal cavity. EAF is the most devastating complication of the open abdomen. We describe and analyze a single institution's experience in controlling high-output EAFs in patients with peritonitis. Methods We analyzed 189 consecutive procedures to achieve and maintain definitive control of 24 EAFs in 13 patients between 2006 and 2017. EAFs followed surgery for either trauma (seven patients) or non-traumatic abdominal conditions (six patients). All procedures were mapped onto an operative timeline and analyzed for: success in achieving definitive control, number of reoperations, and feasibility of bedside procedures in the surgical intensive care unit. The end point was controlled enteric drainage through a healed abdominal wound. Results There was a mean delay of 8.5 days (range 2-46 days) from the index operation until the EAF was identified. Most EAFs required several attempts (mean: 2.7 per patient, range $1-7$ ) until definitive control was achieved. Multiple reoperations were then required to maintain control (mean: 13). While the most effective techniques were endoscopic (1) and proximal diversion (1), these were applicable only in select circumstances. A 'floating stoma' where the fistula edges are sutured to an opening in a temporary closure device, while technically effective, required multiple reoperations. Tube drainage through a negative pressure dressing (tube vac) required the most maintenance usually through bedside procedures. Primary closure almost always failed. Twelve of the 13 patients survived.

Conclusion An EAF is a highly complex surgical challenge. Successful source control of the potentially lethal ongoing peritonitis requires tenacity and tactical flexibility. The appropriate control technique is often found by trial and error and must be creatively tailored to the individual circumstances of the patient.

\section{INTRODUCTION}

With the advent and popularization of open abdomen management for abdominal catastrophes a new entity of fistulae arose, the enteroatmospheric fistulae (EAF). An EAF is an opening in the exposed gut spilling uncontrollably into the peritoneal cavity with limited ability for ostomy mobilization. ${ }^{12}$ The reported incidence ranges from $5 \%$ to $25 \%$ of open abdomens $^{3}$ with a mortality rate as high as $35 \% 0^{4}$ in some series.

Recent literature has focused on prevention of EAFs in an open abdomen through various vacuum and traction techniques. ${ }^{5}$ A multitude of techniques have been described to control effluent and provide wound care. ${ }^{6}$ World surgical societies have attempted to standardize the classification of these heterogeneous groups of patients with various tables and systems. ${ }^{7}$ The aim of this study is to analyze the effectiveness of several operative approaches to control effluent spillage from EAF and subsequent emergence from peritonitis.

\section{METHODS}

We retrospectively reviewed and analyzed 189 consecutive procedures to gain and maintain control of 24 EAFs in 13 patients (20-80 years) during an 11-year period (2006-2017) at a large (637 bed) safety net inner-city level I trauma center. All procedures were mapped onto an operative timeline and analyzed for success in achieving definitive control, number of reoperations needed to maintain control, and for location of the procedure (operating room vs. bedside procedure in the surgical intensive care unit (SICU). Success was defined by control of spillage unto the exposed peritoneum and hence cessation of peritonitis; as characterized by decreasing pressor requirements, normalization of leukocytosis and temperature. Failure of a technique was defined by uncontrolled spillage and sepsis necessitating a switch to a different operative technique.

The end point for the present study was not definitive closure of the fistula (which was undertaken months later) but rather control of enteric output until the abdominal wound granulated around it and was covered with an ostomy appliance.

\section{RESULTS}

In our series, 12 out of 13 patients survived (92.4\%). Uncontrolled leakage into the peritoneal cavity typically required several attempts (mean: 2.7 per patient, range 1-7) to achieve initial control of the EAF followed by additional procedures (mean 11.5, range $0-49$ ) to maintain/regain control until the open abdominal wound granulated and healed around the leak (table 1). EAF followed surgery for either trauma (7 patients, 53\%) or non-traumatic abdominal operations (6 patients, 46\%) (table 2). Mean days from fistula recognition and attempted control until first definitive control was 6.31, and an additional 53.62 days until planned ventral hernia and skin grafting.

The most commonly used successful technique (table 1) was the floating stoma. This technique while effective required multiple trips to the operating room for maintenance procedures. The second most commonly used technique was the tube vac system This system uses tube drainage of the fistula 
Table 1 Operative interventions mapped to an operative timeline including rates of successful control of effluent

\begin{tabular}{lllll}
\hline \multicolumn{2}{l}{ Fistula control techniques } & & & \\
\hline Technique & $\begin{array}{l}\text { Success/ } \\
\text { failure }\end{array}$ & $\begin{array}{l}\text { Success } \\
\text { rate }(\%)\end{array}$ & Reoperations & $\begin{array}{l}\text { At bedside } \\
(\%)\end{array}$ \\
\hline Floating stoma & $7 / 1$ & 88 & 23 & $8(27)$ \\
Tube vac system & $4 / 2$ & 67 & 77 & $73(88)$ \\
Primary closure & $2 / 18$ & 10 & 10 & $4(20)$ \\
Endoscopic control & $2 / 0$ & 100 & 2 & $1(50)$ \\
Proximal diversion & $2 / 0$ & 100 & 11 & $7(54)$ \\
Tube drainage & $1 / 4$ & 20 & 1 & $0(0)$ \\
Continuous irrigation & $0 / 5$ & 0 & 0 & $0(0)$ \\
\hline
\end{tabular}

routed through a negative pressure dressing to provide a pathway of easy egress of enteric contents. The tube vac system was an effective technique but required the most maintenance procedures with the caveat that most could be performed at bedside in the SICU. Endoscopic clipping and stenting were used twice in our series with great efficacy. Proximal diversion was successfully attempted in one case but was complicated by multiple Total Parenteral Nutrition (TPN)related difficulties. Continuous irrigation and primary closure were attempted multiple times without success usually on discovery of the fistula.

\section{DISCUSSION}

The floating stoma and tube vac system were the most versatile and effective techniques, but each required multiple maintenance procedures and vigilance to maintain control, which entails suturing the fistula edges to a temporary closure device, usually an opened saline bag or cassette cover (figure 1). ${ }^{8}$ Creation of the floating stoma, first described in 2002, entails opening a saline bag, mapping the desired location of the ostomy onto the bag. An opening is then made in the bag and the edges are circumferentially sutured using interrupted silk sutures. The edges of the bag are then stapled or sutures to the skin edges and an ostomy appliance is then placed over the created ostomy to control the effluent. The sutures are then replaced as necessary and granulation tissue is allowed to build until a skin graft could be performed.

\begin{tabular}{lll}
\hline $\begin{array}{l}\text { Table } 2 \\
\text { etiology }\end{array}$ & Clinical characteristics of patients by location of fistula and \\
\cline { 1 - 2 } Clinical data & & \\
\hline Etiology & Operation & Proximal vs. distal \\
\hline Trauma & Gunshot wound & Distal \\
\hline Acute care & Mesenteric ischemia & Distal \\
\hline Acute care & Mesenteric ischemia & Proximal \\
\hline Trauma & Gunshot wound & Distal \\
\hline Trauma & Gunshot wound & Proximal \\
\hline Acute care & Internal hernia & Distal \\
\hline Acute care & Internal hernia & Proximal \\
\hline Trauma & Gunshot wound & Proximal \\
\hline Acute care & Colonic necrosis & Distal \\
\hline Trauma & Gunshot wound & Proximal \\
\hline Acute care & Small bowel perforation & Proximal \\
\hline Acute care & Cecal perforation & Proximal \\
\hline Acute care & Mesenteric ischemia & Proximal \\
\hline
\end{tabular}

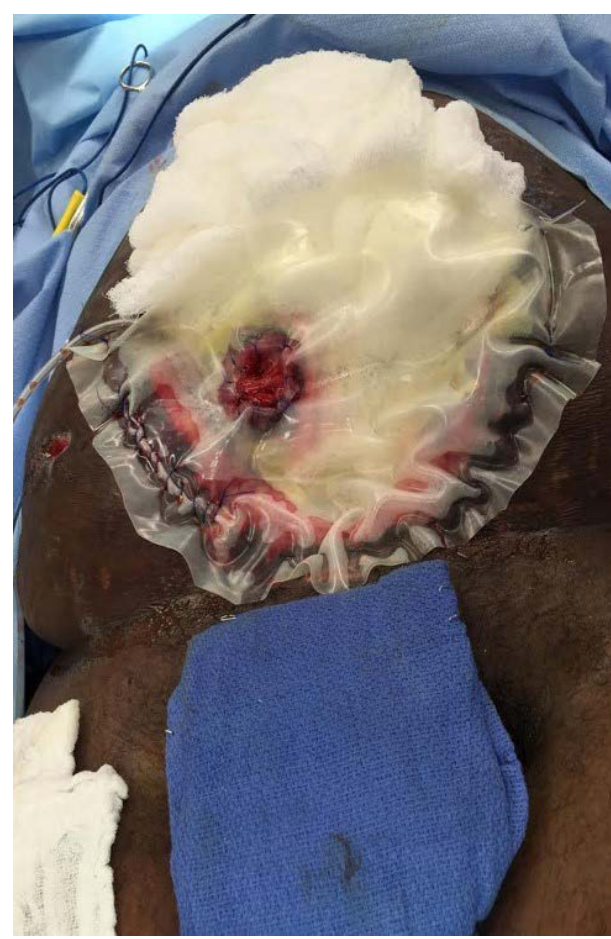

Figure 1 Floating stoma: ostomy and wound edges sutured to saline bag (image used with permission of Dr Asher Hirshberg).

Tube vac system first described in 2008 combines the use of negative pressure vacuum with Malecot drains(figure 2). ${ }^{9}$ Unlike simple intubation of the fistula, which was not met with success in our study, the tube vac system was highly effective but tedious. The EAF is intubated with an appropriately sized drain, the mass of bowel is then covered with white foam followed by typical black sponge and the drain run through an opening created in the sponge. The presumed mechanism by which this technique is thought to be effective is twofold; the first being the negative pressure aids in the formation of granulation tissue, and second by creating a seal around the tube allowing preferential flow of enteric contents through the drain.

Endoscopic control techniques (clipping and stenting) were highly effective and used endoscopically placed clips/stents to control leaks and/or divert enteric effluent away from enteric defects but were limited by endoscopic accessibility of fistulae. ${ }^{10}$

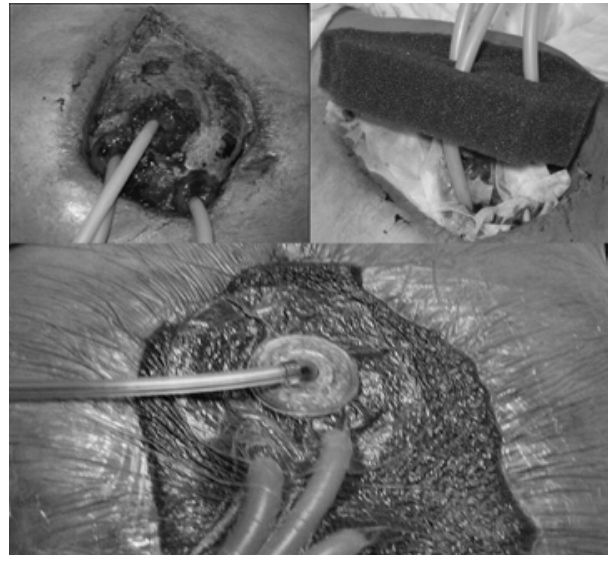

Figure 2 Tube vac system: ostomies intubated with Malecot drains, routed through sponge and Tegaderm dressing applied (image used with permission of Dr Asher Hirshberg). 
Proximal diversion, also known as salvage jejunostomy, before the abdominal visceral mass became 'frozen' was used only in highly select circumstances but was extremely effective. ${ }^{11}$ Continuous irrigation system, using Abramson drains, and primary closure were the least effective techniques. ${ }^{12}$

Our study had several limitations. First, it was a non-randomized retrospective study. Furthermore, the techniques applied were representative of the unique anatomy in our patients. Multiple new techniques have been described with promising early results but were not used at our institution during the study period. ${ }^{13}$ Lastly, despite the long period analyzed at large level 1 trauma center, there were relatively few patients. Our study is unique in mapping an operative timeline in determining effectiveness and tenacity required for each technique.

\section{CONCLUSION}

An EAF is a complex surgical challenge. The mainstays of management include nutritional optimization and support, control of sepsis thought spillage control. A careful analysis of the techniques used to gain and maintain control of the lethal intestinal spillage into the open peritoneal cavity showed very high resource consumption with repeated operations and very long hospital stays. The appropriate control technique chosen must be creatively tailored to the individual circumstances of the patient. Furthermore, these complex patients require tactical flexibility, with willingness to abandon a technique when it appears that it is proving to no longer be effective.

In our hands the two most versatile techniques are the floating stoma and the tube vac as they can be applied in nearly every anatomic circumstance with good success. However, both required significant perseverance to maintain effluent control. Endoscopic control was effective in highly selective circumstances. Early salvage jejunostomy was also highly effective but came at the burden of prolonged course of TPN with multiple readmissions for electrolyte abnormalities, acute kidney injury secondary to massive fluid losses. Primary closure, although tempting, is near universally doomed to failure and should not be attempted. Continuous irrigation was not effective serving only as a temporizing but ineffective technique.

Contributors DJG, TS, MM, VR, LB, and MCS contributed to the design of this study and the editing of the article. DJG, KC, BZS, and EC contributed to data acquisition, analysis and assembly of the article.

Funding The authors have not declared a specific grant for this research from any funding agency in the public, commercial or not-for-profit sectors.

Competing interests None declared.
Patient consent for publication Not required.

Provenance and peer review Not commissioned; externally peer reviewed.

Open access This is an open access article distributed in accordance with the Creative Commons Attribution Non Commercial (CC BY-NC 4.0) license, which permits others to distribute, remix, adapt, build upon this work non-commercially, and license their derivative works on different terms, provided the original work is properly cited, appropriate credit is given, any changes made indicated, and the use is non-commercial. See: http://creativecommons.org/licenses/by-nc/4.0/.

Author note We would like to thank Asher Hirshberg MD for his guidance and pioneering work on this subject

ORCID iD

Daniel Jonathan Gross http://orcid.org/0000-0003-3219-8923

\section{REFERENCES}

1 Schein M, Decker GAG. Gastrointestinal fistulas associated with large abdominal wall defects: experience with 43 patients. Br J Surg 1990;77:97-100.

2 Schecter WP, Hirshberg A, Chang DS, Harris HW, Napolitano LM, Wexner SD, Dudrick SJ. Enteric fistulas: principles of management. J Am Coll Surg 2009;209:484-91.

3 Bradley MJ, Dubose JJ, Scalea TM, Holcomb JB, Shrestha B, Okoye O, Inaba K, Bee TK, Fabian TC, Whelan JF, et al. Independent predictors of enteric fistula and abdominal sepsis after damage control laparotomy: results from the prospective AAST open abdomen registry. JAMA Surg 2013;148:947-54.

4 Rasilainen SK, Viljanen M, Mentula PJ, Leppäniemi AK. Enteroatmospheric fistulae in open abdomen: management and outcome - single center experience. Int J Surg Open 2016:5:44-9.

5 Tolonen M, Mentula P, Sallinen V, Rasilainen S, Bäcklund M, Leppäniemi A. Open abdomen with vacuum-assisted wound closure and mesh-mediated fascial traction in patients with complicated diffuse secondary peritonitis: a single-center 8-year experience. J Trauma Acute Care Surg 2017;82:1100-5.

6 Di Saverio S, Tarasconi A, Inaba K, Navsaria P, Coccolini F, Costa Navarro D, Mandrioli M, Vassiliu P, Jovine E, Catena F, et al. Open abdomen with concomitant enteroatmospheric fistula: attempt to rationalize the approach to a surgical nightmare and proposal of a clinical algorithm. J Am Coll Surg 2015;220:e23-33.

7 Björck M, Bruhin A, Cheatham M, Hinck D, Kaplan M, Manca G, Wild T, Windsor A. Classification-Important step to improve management of patients with an open abdomen. World J Surg 2009;33:1154-7.

8 Subramaniam MH, Liscum KR, Hirshberg A. The floating stoma: a new technique for controlling exposed fistulae in abdominal trauma. J Trauma 2002;53:386-8.

9 Al-Khoury G, Kaufman D, Hirshberg A. Improved control of exposed fistula in the open abdomen. J Am Coll Surg 2008;206:397-8.

10 DW Y, Hong MY, Hong SG. Endoscopic treatment of duodenal fistula after incomplete closure of ERCP-related duodenal perforation. World J Gastrointest Endosc 2014:6:260-5.

11 Rebibo L, Wacrenier A, Thiebault H, Delcenserie R, Regimbeau J-M. Combined endoscopic and surgical covered stent placement: a new tailored treatment for enteroatmospheric fistula in patients with terminal ileostomy. Endoscopy 2017:49:E35-6.

12 Levy E, Frileux P, Cugnenc PH, Parc R, Ollivier JM, Honiger J, Tiret E, Loygue J. [Exposed fistula of the small intestine, a complication of peritonitis or laparotomy. Apropos of 120 cases]. Ann Chir 1986:40:184-95.

13 Layton B, Dubose J, Nichols S, Connaughton J, Jones T, Pratt J. Pacifying the open abdomen with concomitant intestinal fistula: a novel approach. Am J Surg 2010;199:e48-50. 